\title{
The system Tetrabothrius bassani (Tetrabothriidae)/ Morus bassanus (Sulidae) as a bioindicator of marine heavy metal pollution
}

\author{
Paula Mendes', Catarina Eira ${ }^{2,3}$, José Vingada ${ }^{1,2,3}$, Jordi Miquel ${ }^{4,5}$ and Jordi Torres ${ }^{4,5 *}$ \\ ${ }^{1}$ Departamento de Biologia, Universidade do Minho, Campus de Gualtar, 4710-057 Braga, Portugal; \\ ${ }^{2}$ CESAM \& Departamento de Biologia, Universidade de Aveiro, Campus de Santiago 3810-193 Aveiro, Portugal; \\ ${ }^{3}$ Sociedade Portuguesa de Vida Selvagem, Estação de Campo de Quiaios, Apartado 16 EC Quiaios 3081-101 Figueira da Foz, Portugal; \\ ${ }^{4}$ Laboratori de Parasitologia, Departament de Microbiologia i Parasitologia Sanitàries, Facultat de Farmàcia, Universitat de Barcelona. \\ Av. Joan XXIII, s/n 08028, Barcelona, Spain; ${ }^{5}$ Institut de Recerca de la Biodiversitat, Universitat de Barcelona, Av. Diagonal, 645, \\ 08028 Barcelona, Spain
}

\begin{abstract}
Helminths are known to accumulate higher amounts of certain elements than their hosts. The present study assesses the accumulation of heavy metals in Tetrabothrius bassani and in its host, the Atlantic gannet (Morus bassanus) found dead due to bycatch along the seashore in the centre of Portugal. Samples of kidney, liver and pectoral muscle of 23 infected gannets, as well as specimens of T. bassani were analysed for $\mathrm{As}, \mathrm{Cd}, \mathrm{Cr}, \mathrm{Cu}, \mathrm{Hg}, \mathrm{Mn}, \mathrm{Pb}, \mathrm{Se}$ and $\mathrm{Zn}$ by ICP-MS. The evidenced lower concentrations of $\mathrm{Cr}$ and $\mathrm{Pb}$ in tissues of gannets in comparison to an earlier study performed in the same area may reveal a change in the diet of M. bassanus between both study periods. The highest bioaccumulation factor was obtained for $\mathrm{Cd}$ with a 12.7times higher concentration in the cestode than in gannet muscle. Lead concentration in T. bassani was 6.9-times higher than in kidney tissue, 8.5-times higher than in muscle and 9.5-times higher than in liver of M. bassanus. The cestode/seabird system T. bassani/M. bassanus can be considered a promising bioindicator system to monitor environmental $\mathrm{Cd}$ and $\mathrm{Pb}$ pollution in marine ecosystems.
\end{abstract}

\section{Keywords}

Tetrabothrius bassani, Morus bassanus, heavy metals, helminth/seabird system

\section{Introduction}

Studies on the interactions between pollution and parasites have been increasing over the last years and it is known that some helminths are able to accumulate heavy metals in concentrations higher than their hosts (Sures 2003, 2004). High bioaccumulation factors have been reported in parasite/host systems involving acanthocephalans of fish (Sures and Taraschewski 1995, Sures and Siddall 1999, Sures et al. 2005, Brázová et al. 2012, Jankovska et al. 2012). Cestodes have been also found to accumulate relatively high amounts of heavy metals and therefore several cestode/fish systems were also proposed as useful indicators of heavy metal pollution in the aquatic environment (Jirsa et al. 2008, Eira et al. 2009, Brázová et al. 2012).

However, data on parasite-host systems as bioindicators of heavy metal pollution in the marine environment are still scarce considering that the available information mainly concerns freshwater or estuarine ecosystems. In fact, the available data on parasites of marine hosts refer to only a few cestode and nematode species. The studied cestodes are Bothriocephalus scorpii infecting turbots (Scophthalmus maximus) from the coast of Poland (Sures et al. 1997) and Anthobothrium sp. and Paraorigmatobothrium sp. parasitizing the shark (Carcharhinus dussumieri) from the Persian Gulf (Malek et al. 2007). The studied nematodes include Anisakis simplex s.l. infecting cetaceans (Pascual and Abollo 2003), Hysterothylacium aduncum parasitizing Sparus aurata in the Iskenderun Bay (Dural et al. 2011) and Hysterothylacium sp. type MB larvae infecting Trichiurus lepturus in the Gulf of Oman (Khaleghzadeh-Ahangar et al. 2011).

Heavy metals in marine environments emerge through different pathways (waste products, industrial activities and natural processes). Their biomagnification along the food chain 
is a major concern in marine environments, increasing the potential for human exposure (Mulvad et al. 1996, Ross 2000, Li et al. 2010). In this context, other than fish and cetaceans, seabirds have been often used as bioindicators of heavy metals in the marine environment because they are long-lived and feed at different distances from land, and because of their high trophic position, exhibiting different trophic levels (Hahn et al. 1993, Burger and Gochfeld 2000, Savinov et al. 2003, Mallory et al. 2010). Contrarily, the evaluation of parasite-seabird host systems in heavy metal pollution biomonitoring is still scarce. Systems involving birds living in freshwater ecosystems have already been proposed (Barus et al. 2000, Tenora et al. 2002), but there are no data concerning marine birds except for two cormorant species (Phalacrocorax carbo and P. auritus) which are more coastal rather than truly oceanic birds being used to colonise inland waters (Barus et al. 2001, Robinson et al. 2010).

The purpose of this study was to assess the accumulation of trace elements in Tetrabothrius bassani Burt, 1978 (Cestoda: Tetrabothriidae) in relation to its host Morus bassanus Linnaeus, 1758 (Pelecaniformes: Sulidae), and evaluate this system as the first cestode/seabird bioindicator for heavy metals pollution in the marine environment.

\section{Materials and Methods}

Twenty-three Atlantic gannets (M. bassanus) parasitized by $T$. bassani were used to perform the present study. All individuals were found dead due to by-catch (accidental capture by fishing gear) in 2007 and 2008 in the central coast of Portugal $\left(40^{\circ} 13^{\prime} 14^{\prime \prime} \mathrm{N}\right.$ and $\left.8^{\circ} 53^{\prime} 31^{\prime \prime} \mathrm{W}\right)$. Cause of death was confirmed during necropsies. Apart entangled nets, fractures, abrasions and cuts in wings and legs, all gannets presented good body condition, undigested fish in proventriculi and haemorrhagic lungs. The digestive tracts of gannets were scanned for helminths using a stereomicroscope with the help of stainless steel instruments and Milli-Q water. At least one individual of T. bassani from each parasitized M. bassanus, as well as re- spective samples of kidney, liver and pectoral muscle tissues were collected and stored in glass vials and deep-frozen until posterior analysis.

Kidney, liver and pectoral muscle samples of the 23 gannets studied ( $\pm 150 \mathrm{mg}$ wet weight) as well as the respective T. bassani specimens were individually digested in Teflon vessels with $\mathrm{HNO}_{3}(2 \mathrm{ml})$ and $\mathrm{H}_{2} \mathrm{O}_{2}(1 \mathrm{ml})$ (Merck, Suprapure) at $90^{\circ} \mathrm{C}$ in an oven and left overnight. All material used in the digestion process was thoroughly acid-rinsed. After digestion, samples were diluted with Milli-Q water and then analysed for $\mathrm{As}, \mathrm{Cd}, \mathrm{Cr}, \mathrm{Cu}, \mathrm{Hg}, \mathrm{Mn}, \mathrm{Pb}, \mathrm{Se}$ and $\mathrm{Zn}$ in an inductively coupled plasma mass spectrometer (Perkin Elmer Elan 6000). The analytical procedure was checked using standard reference material: Squalus acanthias liver (DOLT-3) and Squalus acanthias muscle (DORM-2) both provided by the National Research Council of Canada. Analytical blanks were also used to determine the detection limits.

Concentrations of most of the evaluated elements were not normally distributed, thus Kruskal-Wallis and post-hoc Dunn's tests were used. All analyses were performed in Prism 5.0 (Graph Pad Software Inc). A significance level of $\mathrm{P}<0.05$ was applied for all tests. The bioaccumulation factors were determined as the ratio of the element concentration in the parasites to that in different host tissues $\left(\mathrm{BF}=\mathrm{C}_{\text {[parasite] }} / \mathrm{C}_{\text {[host tissue] }}\right)$ according to Sures et al. (1999).

\section{Results}

Tetrabothrius bassani was the only intestinal helminth present in the analysed gannets. The detection limits for the evaluated elements were inferior to $1 \mathrm{ng} \mathrm{ml}^{-1}$ except for $\mathrm{Zn}\left(5.8 \mathrm{ng} \mathrm{ml}^{-1}\right)$. With respect to the analytical procedure, considering the elements present in the respective reference material, ICP-MS analysis revealed accuracy rates ranging between $85.1 \%$ for $\mathrm{Cu}$ and $105.3 \%$ for Se. Mean values ( \pm standard errors) and ranges of all element concentrations found in kidney, liver and muscle of M. bassanus and those found in T. bassani are summarized in Table I.

Table I. Mean element concentration ( \pm standard error, SE) and range values in soft tissues of Morus bassanus and in Tetrabothrius bassani ( $\mu \mathrm{g} \mathrm{g}^{-1}$ wet weight) from Portugal

\begin{tabular}{|c|c|c|c|c|c|c|c|c|}
\hline & \multicolumn{2}{|c|}{ Kidney } & \multicolumn{2}{|c|}{ Liver } & \multicolumn{2}{|c|}{ Muscle } & \multicolumn{2}{|c|}{ Cestode } \\
\hline & Mean (SE) & Range & Mean (SE) & Range & Mean (SE) & Range & Mean (SE) & Range \\
\hline As & $0.528(0.046)$ & $0.258-1.215$ & $0.465(0.052)$ & $0.145-1.188$ & $0.707(0.058)$ & $0.314-1.432$ & $0.811(0.077)$ & $0.096-1.789$ \\
\hline $\mathrm{Cr}$ & $0.378(0.029)$ & $0.110-0.635$ & $0.406(0.061)$ & $0.082-1.576$ & $0.621(0.063)$ & $0.215-1.682$ & $0.759(0.128)$ & $0.160-3.157$ \\
\hline $\mathrm{Cu}$ & $4.545(0.472)$ & $2.425-12.685$ & $7.377(0.625)$ & $2.797-15.231$ & $4.290(0.345)$ & $2.045-9.077$ & $2.065(0.213)$ & $0.017-4.503$ \\
\hline $\mathrm{Pb}$ & $0.036(0.006)$ & $0.015-0.110$ & $0.026(0.005)$ & $0.015-0.130$ & $0.029(0.063)$ & $0.014-0.082$ & $0.247(0.165)$ & $0.009-3.904$ \\
\hline $\mathrm{Se}$ & $5.185(0.787)$ & $1.540-14.667$ & $4.531(0.739)$ & $1.028-13.334$ & $1.364(0.250)$ & $0.295-5.345$ & $1.048(0.121)$ & $0.168-2.753$ \\
\hline $\mathrm{Zn}$ & $36.489(2.901)$ & $24.241-78.298$ & $59.631(8.265)$ & $22.026-152.772$ & $30.781(2.610)$ & $15.127-63.698$ & 70.931 (7.809) & $6.194-188.797$ \\
\hline & & & & & Inloaded from & e Gruyter Online & $\begin{array}{l}0.2478 / \mathrm{s} 11686-01 \\
\text { at 09/29/2016 } 12 \\
\text { via Universidade }\end{array}$ & $\begin{array}{l}3-0102-5 \\
\text { 28:16PM } \\
\text { de Aveiro }\end{array}$ \\
\hline
\end{tabular}


Table II. Bioaccumulation factors (range), $[\mathrm{C}]_{\text {parasite }} /[\mathrm{C}]_{\text {host tissue }}$, evidenced in Tetrabothrius bassani in relation to Morus bassanus tissues

\begin{tabular}{lccc}
\hline & $\mathbf{B F}_{\text {Kidney }}$ & $\mathbf{B F}_{\text {Liver }}$ & $\mathbf{B F}_{\text {Muscle }}$ \\
\hline $\mathrm{As}$ & $1.5(0.2-3.9)$ & $1.7(0.4-4.6)$ & $<1$ \\
$\mathrm{Cd}$ & $<1$ & $<1$ & $12.7(1.3-106.3)$ \\
$\mathrm{Cr}$ & $2.0(0.4-9.0)$ & $1.9(0.3-6.8)$ & $<1$ \\
$\mathrm{Mn}$ & $<1$ & $<1$ & $3.4(0.2-69.3)$ \\
$\mathrm{Pb}$ & $6.9(0.1-60.7)$ & $9.5(0.4-237.1)$ & $8.5(0.2-57.1)$ \\
$\mathrm{Zn}$ & $1.9(0.2-7.7)$ & $<1$ & $2.3(0.3-5.6)$ \\
\hline
\end{tabular}

Some trace elements presented significantly higher average concentrations in seabird tissues than in the cestode such as $\mathrm{Cu}$ in liver, kidney and muscle tissue, Se in liver and kidney, and $\mathrm{Mn}$ in liver (Kruskal-Wallis, $49.4<\mathrm{H}<52.06$, $\mathrm{P}<0.0001$; Dunn's test, $\mathrm{P}<0.001$ ). There were also significantly higher average concentrations of $\mathrm{Cd}$ in gannet's kidney and $\mathrm{Hg}$ in liver (Kruskal-Wallis, $\mathrm{H}=45.61$ and $\mathrm{H}=43.29$, $\mathrm{P}<0.0001$, respectively) in comparison to those in cestodes (Dunn's test, $\mathrm{P}<0.001$ ). However, average concentrations of $\mathrm{As}, \mathrm{Cr}, \mathrm{Mn}$ and $\mathrm{Zn}$ in T. bassani were significantly higher than those found in some M. bassanus soft tissues (Kruskal-Wallis, $19.5<\mathrm{H}<49.4, \mathrm{P}<0.0002$ ). This is the case of As and $\mathrm{Cr}$ concentrations in the cestode when compared to values in kidney and liver tissues (Dunn's test, $\mathrm{P}<0.05$ ). Also the concentrations of $\mathrm{Mn}$ in seabird muscle tissue and the concentrations of $\mathrm{Zn}$ in kidney and muscle tissue were significantly lower than those in the cestode $(\mathrm{P}<0.05)$.

The highest significant bioaccumulation factor $(\mathrm{BF})$ was found for $\mathrm{Cd}$, with a 12.7-times higher average concentration in the cestode in comparison to gannet muscle (Kruskal-Wallis, $\mathrm{H}=45.61, \mathrm{P}<0.05$ ) with a maximum value of 106.3 (Table II). High average $\mathrm{BFs}$ were obtained for $\mathrm{Pb}$ with respect to kidney $(\mathrm{BF}=6.9)$, liver $(\mathrm{BF}=9.5)$ and muscle $(\mathrm{BF}=8.5)$ (Table II). However, the $\mathrm{Pb}$ concentrations in the cestode were not considered significantly higher than those in gannet's tissues (Kruskal-Wallis, $\mathrm{H}=5.32, \mathrm{P}=0.15$ ).

\section{Discussion}

In a previous study focused on non-parasitized M. bassanus collected during the period 2003-2006 in the same area of Portugal, among other toxic elements, a high concentration of mercury was reported, which could represent an early warning indication of pollution (Mendes et al. 2008) since the concentrations of mercury in gannets were roughly above the minimum concentration for adverse effects in birds (Eisler 1987).

Mendes et al. (2008) report dry weight-based trace element concentrations and humidity percentage values in kidney, liver and muscle samples of M. bassanus, thus allowing us to transform their data into wet weight values. We were then able to verify that most element concentrations in gannets presented in our study are within the range of the values reported by Mendes et al. (2008). However, our results indi- cate relatively lower concentrations of $\mathrm{Cr}$ and $\mathrm{Pb}$ in kidney, liver and muscle samples and also higher concentrations of $\mathrm{Hg}$ in liver in comparison to liver tissue in any of the gannets' age classes reported in Mendes et al. (2008). Even though a high concentration of $\mathrm{Hg}$ is expected in such predatory seabirds, our results seem to corroborate the earlier study on gannets with respect to the above-mentioned potential $\mathrm{Hg}$ pollution. In general the relative differences between the values presently reported and those from birds evaluated by Mendes et al. (2008) may result from a different use of food resources, considering diet's confirmed role as a major contamination pathway in marine vertebrates (Kim et al. 1998).

An earlier assessment of the cestode/fish system Proteocephalus macrocephalus/Anguilla anguilla from an estuarine environment in Portugal (Ria de Aveiro) suggested that the cestode accumulated $\mathrm{Cr}$ and $\mathrm{Ni}$ while the concentrations of $\mathrm{Cr}$ in eel livers and $\mathrm{Ni}$ in eel kidneys were comparatively lower (Eira et al. 2009). Lower metal contents in fish hosting helminth parasites in comparison to fish without parasites have been described in other studies (Malek et al. 2007, Brázová et al. 2012). Even though the toxic element concentrations reported in the present set of gannets were not compared to those from another set of not infected specimens, the present data concur with the possible antagonistic effect of simultaneously occurring parasites and pollutants, since parasites seem to act as heavy metal filters or sinks removing them from host tissues (Sures 2008). In fact, considering the obtained bioaccumulation factors between $T$. bassani and M. bassanus, relevant values were obtained for $\mathrm{Cd}$ and $\mathrm{Pb}$. With respect to $\mathrm{Cd}$ a very high average $\mathrm{BF}$ was registered in relation to seabird muscle $\left(\mathrm{BF}_{\mathrm{Cd}}=12.7\right)$ with a maximum $\mathrm{BF}_{\mathrm{Cd}}$ of 106.3. This value is much higher than that found for another helminth/bird system in a previous study on Raillietina micracantha/Columba livia from an urban environment (maximum $\mathrm{BF}_{\mathrm{Cd} \text {,muscle }}=57.25$ ) performed by Torres et al. (2010). Although an higher number of samples should be assessed in the future to validate the significance of the $\mathrm{Pb}$ bioaccumulation factors, in the present study the $\mathrm{BFs}$ calculated for $\mathrm{Pb}$ with respect to liver, kidney and muscle indicated between 7 to 10 times more $\mathrm{Pb}$ in T. bassani than in the gannet's soft tissues (Table II). Cestodes absorb nutrients across their tegument from the host intestinal lumen and therefore the higher amount of $\mathrm{Pb}$ in the cestode than those in kidney or liver of $M$. bassanus either indicates that seabirds may be able to excrete the circulating $\mathrm{Pb}$ to the 
intestinal lumen and/or that T. bassani act as sinks and therefore accumulate lead in their own tissues as occurs in acanthocephalans (Sures and Sidall 1999).

In conclusion the relative differences between the present results and those reported in Mendes et al. (2008), namely lower concentrations of $\mathrm{Cr}$ and $\mathrm{Pb}$ in soft tissues and higher concentrations of $\mathrm{Hg}$ in liver, emphasise the importance of feeding diversity on toxic element variability. Therefore, seabird dietary preferences and changes are subjects that should be considered in biomonitoring studies. The most elevated $\mathrm{BFs}$ were registered for $\mathrm{Cd}$ respect to muscle and $\mathrm{Pb}$ respect to liver, kidney and muscle. The present data seems to be in agreement with the possible antagonistic effects of some helminths and heavy metal pollution on host health (see Sures 2008). Although more field essays are necessary to evaluate the relationship between bioaccumulation in cestode parasites of birds and environmental trace element availability, considering the BFs obtained in the present study the system T. bassani/M. bassanus can be proposed as a promising bioindicator system to evaluate $\mathrm{Cd}$ and $\mathrm{Pb}$ in marine environments.

Acknowledgements. This study was financed by the Grup de Recerca Consolidat 2009 SGR 403 de la Generalitat de Catalunya and also by fellowships SFRH/BD/42100/2007 and SFRH/BPD/27014 /2006 provided by the Fundação para a Ciência e Tecnologia under QREN-POPH co-financed by the Fundo Social Europeu and the Portuguese Ministry of Education and Science. The authors wish to thank all personnel at the "Centres Científics i Tecnològics de la Universitat de Barcelona (CCiTUB)" for their support.

\section{References}

Barus V., Tenora F., Krácmar S. 2000. Heavy metal (Pb, Cd) concentrations in adult tapeworms (Cestoda) parasitizing birds (Aves). Helminthologia, 37, 131-136.

Barus V., Tenora F., Krácmar S., Prokes M. 2001. Cadmium and lead concentrations in Contracaecum rudolphii (Nematoda) and its host, the cormorant Phalacrocorax carbo (Aves). Folia Parasitologica, 48, 77-78.

Brázová T., Torres J., Eira C., Hanzelová V., Miklisová D., Salamún P. 2012. Perch and its parasites as heavy metal biomonitors in a freshwater environment: the case study of the Ruzín water reservoir, Slovakia. Sensors, 12, 3068-3081. DOI: 10.3390/ s120303068.

Burger J., Gochfeld M. 2000. Metal levels in feathers of 12 species of seabirds from Midway Atoll in the northern Pacific Ocean. Science of the Total Environment, 257, 37-52.

Dural M., Genc E., Sangun M.K., Güner O. 2011. Accumulation of some heavy metals in Hysterothylacium aduncum (Nematoda) and its host sea bream, Sparus aurata (Sparidae) from NorthEastern Mediterranean Sea (Iskenderun Bay). Environmental Monitoring and Assessment, 174, 147-155. DOI: 10.1007/ s10661-010-1445-0.

Eira C., Torres J., Miquel J., Vaqueiro J., Soares A., Vingada J. 2009. Trace element concentrations in Proteocephalus macrocephalus (Cestoda) and Anguillicola crassus (Nematoda) in comparison to their fish host, Anguilla anguilla in Ria de Aveiro, Portugal. Science of the Total Environment, 407, 991998. DOI: 10.1016/j.scitotenv.2008.10.040.
Eisler R. 1987. Mercury hazards to fish, wildlife, and invertebrates: a synoptic review. U.S. Fish and Wildlife Service Biological Report 85 (1.10). Washington.

Hahn E., Hahn K., Stoeppler M. 1993. Bird feathers as bioindicators in areas of the German environmental specimen bank - bioaccumulation of mercury in food chains and exogenous deposition of atmospheric pollution with lead and cadmium. Science of the Total Environment, 139/140, 259-270. DOI: 10.1016/ 0048-9697(93)90025-2.

Jankovska I., Miholova D., Lukesova D., Kalous L., Valek P., Romocusky S., Vadlejch J., Petrtyl M., Langrova I., Cadkova Z. 2012. Concentrations of $\mathrm{Zn}, \mathrm{Mn}, \mathrm{Cu}$ and $\mathrm{Cd}$ in different tissues of perch (Perca fluviatilis) and in perch intestinal parasite (Acanthocephalus lucii) from the stream near Prague (Czech Republic). Environmental Research, 112, 83-85. DOI: 10.1016/j.envres.2011.11.003.

Jirsa F., Leodolter-Dvorak M., Krachler R., Frank C. 2008. Heavy metals in the nase, Chondrostoma nasus (L. 1758), and its intestinal parasite Caryophyllaeus laticeps (Pallas 1781) from Austrian Rivers: Bioindicative Aspects. Archives of Environmental Contamination and Toxicology, 55, 619-626. DOI: 10.1007/s00244-008-9154-1.

Khaleghzadeh-Ahangar H., Malek M., McKenzie K. 2011. The parasitic nematodes Hysterothylacium sp. type MB larvae as bioindicators of lead and cadmium: a comparative study of parasite and host tissues. Parasitology, 138, 1400-1405. DOI: 10.1017/S0031182011000977.

Kim E.Y., Goto R., Tanabe S., Tanaka H., Tatsukawa R. 1998. Distribution of 14 trace elements in tissues and organs of oceanic seabirds. Archives of Environmental Contamination and Toxicology, 35, 638-645. DOI: 10.1007/s002449900426.

Li P., Feng X.B., Qiu G.L. 2010. Methylmercury exposure and health effects from rice and fish consumption: a review. International Journal of Environmental Research and Public Health, 7, 2666-2691. DOI: 10.3390/ijerph7062666.

Malek M., Haseli M., Mobedi I., Ganjali M.R., Mackenzie K. 2007. Parasites as heavy metal bioindicators in the shark Carcharhinus dussumieri from the Persian Gulf. Parasitology, 134, 1053-1056. DOI: $10.1017 / \mathrm{S} 0031182007002508$.

Mallory M.L., Robinson S.A., Hebert C.E., Forbes M.R. 2010. Seabirds as indicators of aquatic ecosystem conditions: a case for gathering multiple proxies of seabird health. Marine Pollution Bulletin, 60, 7-12. DOI: 10.1016/j.marpolbul.2009.08.024.

Mendes P., Eira C., Torres J., Soares A., Melo P., Vingada J. 2008. Toxic element concentration in the Atlantic gannet Morus bassanus (Pelecaniformes, Sulidae) in Portugal. Archives of Environmental Contamination and Toxicology, 55, 503-509. DOI: $10.1007 / \mathrm{s} 00244-008-9134-5$.

Mulvad G., Pedersen H.S., Hansen J.C., Dewailly E., Jul E., Pedersen M.B., Bjerregaard P., Malcom G.T., Deguchi Y., Middaugh J.P. 1996. Exposure of Greenlandic Inuit to organochlorines and heavy metals through the marine foodchain: an international study. Science of the Total Environment, 186, 137-139. DOI: 10.1016/0048-9697(96)05093-0.

Pascual S., Abollo E. 2003. Accumulation of heavy metals in the whaleworm Anisakis simplex s.l (Nematoda: Anisakidae). Journal of the Marine Biological Association of the United Kingdom, 83, 905-906. DOI: 10.1017/S0025315403008038h.

Robinson S.A., Forbes M.R., Hebert C.E. 2010. Mercury in parasitic nematodes and trematodes and their double-crested cormorant hosts: bioaccumulation in the face of sequestration by nematodes. Science of the Total Environment, 408, 5439-5444. DOI: 10.1016/j.scitotenv.2010.07.071

Ross P.S. 2000. Marine mammals as sentinels in ecological risk assessment. Human and Ecological Risk Assessment, 6, 29-46. DOI: $10.1080 / 10807030091124437$. 
Savinov V.M., Gabrielsen G.W., Savinova T.N. 2003. Cadmium, zinc, copper, arsenic, selenium and mercury in seabirds from the Barents Sea: levels, inter-specific and geographical differences. Science of the Total Environment, 306, 133-158. DOI: 10.1016/S0048-9697(02)00489-8.

Sures B. 2003. Accumulation of heavy metals by intestinal helminths in fish: an overview and perspectives. Parasitology, 126, S53S60. DOI: 10.1017/S003118200300372X.

Sures B. 2004. Environmental Parasitology: relevance of parasites in monitoring environmental pollution. Trends in Parasitology, 20, 170-177. DOI: 10.1016/j.pt.2004.01.014.

Sures B. 2008. Environmental parasitology. Interactions between parasites and pollutants in the aquatic environment. Parasite, 15, 434-438.

Sures B., Siddall R. 1999. Pomphorhynchus laevis: the intestinal acanthocephalan as a lead sink for its fish host, chub (Leuciscus cephalus). Experimental Parasitology, 93, 66-72. DOI: 10.1006/expr.1999.4437.

Sures B., Siddall R., Taraschewski H. 1999. Parasites as accumulation indicators of heavy metal pollution. Parasitology Today, 15, 16-22. DOI: 10.1006/S0169-4758(98)01358-1

Sures B., Taraschewski H. 1995. Cadmium concentrations in two adult acanthocephalans, Pomphorhynchus laevis and Acanthocephalus lucii, as compared with their fish hosts and cad- mium and lead levels in larvae of A. lucii as compared with their crustacean host. Parasitology Research, 81, 494-497. DOI: 10.1007/BF00931792.

Sures B., Taraschewski H., Rokicki J. 1997. Lead and cadmium content of two cestodes, Monobothrium wageneri and Bothriocephalus scorpii, and their fish hosts. Parasitology Research, 83, 618-623. DOI: 10.1007/s004360050307.

Sures B., Thielen F., Baska F., Messerschmidt J., von Bohlen A. 2005. The intestinal parasite Pomphorhynchus laevis as a sensitive accumulation indicator for the platinum group metals Pt, Pd, and Rh. Environmental Research, 98, 83-88. DOI: 10.1016/j.envres.2004.05.010.

Tenora F., Barus V., Prokes M. 2002. Next remarks to the knowledge of heavy metal concentrations in gravid tapeworm species parasitizing aquatic birds. Helminthologia, 39, 143-148.

Torres J., Foronda P., Eira C., Miquel J., Feliu C. 2010. Trace element concentrations in Raillietina micracantha in comparison to its definitive host, the feral pigeon Columba livia in Santa Cruz de Tenerife (Canary Archipelago, Spain). Archives of Environmental Contamination and Toxicology, 58, 176182. DOI: $10.1007 / \mathrm{s} 00244-009-9352-5$.

(Accepted October 09, 2012) 